Прегледни чланак

doi:10.5937/zrpfns51-15059

Veronika Szikora, Ph.D., Associate Professor

University of Debrecen

Faculty of Law

szikora.veronika@law.unideb.hu

Gabor Szilagyi,Master Studies Student

szilagyi.gaben@gmail.com

\title{
NEW DANGEROUS PRACTICE ON THE HORIZON? LEGAL ASPECTS OF DRONE USAGE
}

Abstract: The reason why we have chosen this topic for the subject of this research is the new technologies emerging around us, particularly the unnamed aerial vehicles (UAV). In Hungary, similarly to some other countries, there is a gap in legislation concerning the use of UAV.

The UAV technology raises many questions since these vehicles can be used for several purposes. It is necessary to analyze in depth the legal environment of UAV and to change our perspective as it is not enough to consider the legal context; technical and other aspects should be taken into consideration too.

Most academic sources related to the usage of UAV focus on the military use of the technology. In our research, we put an emphasis on the various aspects of civil law; the reason for this approach is that we consider the legal restrictions concerning the ordinary vehicles used for everyday purposes and not for governmental ones.

The main goal of our paper is to study how the usage of UAV can be legally controlled. This question is important as the number of these vehicles are gradually growing. This tendency raises several legal issues like privacy or tort.

In our research, we have analyzed international laws and regulatory plans, national laws, and draft legislation. The ,abnormally dangerous activities" that appear in the title of the paper is an indication that we consider the liability aspect of the problem an important issue.

The other aim of our paper is to make a proposal to set up a work group that is going to work out the regulations in detail. Legislators and researchers could participate in the work group, among whom technical and legal professionals may merge their forces.

Keywords: Civil UAV, Civil drone, Civil liability, Dangerous practice. 


\section{INTRODUCTION AND OBJECTIVES}

In today's rapidly changing world, new elements and contents have emerged in our physical and legal environment, which, in addition to traditional classical legal thinking and methods, call for a more appropriate approach among lawmakers and law enforcers as well. This challenge is clearly shown in solving the legal problems arising from the operation of unmanned vehicles. ${ }^{1}$

The theme selection was generated by the recognition that unmanned vehicles, including unmanned aerial vehicles, i.e. drones (according to English terminology: UAVs), appear not only in the air, but also on the legal horizon, and that drones will be the focus of not too distant future disputes and scientific exchanges.

The legal problem of unmanned vehicles is basically related to liability issues arising from the issue of responsibility, from which available research results have already been produced, and disputes have already emerged at the trial stage about accidents, from which court orders have come forth. These issues, due to the wide spread use of drones, are soon to be expected in this area - away from the ground.

Even in the five-thousand-year-old Greek myth of Icarus, the curiosity of human nature appeared to conquer nature; "Who would never have dreamed of flying?"2 Man is striving to conquer nature, which is not subject to certain human domination.

The question asked in the title: "A new hazardous practice on the horizon?" is an alert. Can flying a drone be regarded as a really dangerous practice? Can the hazardous practice scope be expanded by the drone? In answer to the question - as a hypothesis - we declare: yes, but arguments can also weaken the foundations of our finding.

According to the state of the technology today, drones do not carry people, but it is conceivable that they may in the future, and it is even feasible with the advances in technology. It is clear the dangerous practice nature of them is without any doubt. On the horizon, we can plan for the near and more distant future, but the occurrence of these future events cannot be seen in advance, so this is why it is necessary to leave the question open.

The thesis deals with issues relating to the state of technology in the present day, and it addresses and provides adequate legal responses. It is important that the follow-up of technical progress and appropriate legal conclusions are inseparable from each other.

Several areas of application of drones can be examined, which may be state, military or other aspects. The paper focuses on civic, hobby and commercial activities.

${ }^{1}$ The closing date of the manuscript: October 25, 2016.
${ }^{2}$ Berényi, 1998, 34. 
During the exploration of the literature about drones, we found that a large number of sources are available, but most of them are aimed at military (tactical) usage. The sources and the literature that examine the relations between civil use and law can only be found in a very limited number. It also shows that this area is still "expanding its wings", as this usage aspect has appeared in the market over the past few years and became available to the household user.

Drone technology embraces questions and opportunities that many people cannot imagine, and the potential for use can only be limited by our imagination. Based on these findings, it can be said that the possibility of legal regulation of drones, and their in-depth and complex analysis is still waiting for itself, but its necessity can be justified without any doubt. One of the goals of the thesis is to add something to this discussion, and to answer the questions.

This topic is only worth investigating effectively in a multidisciplinary way. In addition to civil law, the thorough and complex examination of administrative law, criminal justice and other disciplines, the image of the legal judgment of drones can be developed. In view of this diversity, we have taken into consideration the relevant legislation currently in force, in particular the Act V of 2013 on Civil Code (hereinafter referred to as "Ptk") and the Act XCVII of 1995 on Air Transport (hereinafter Lt), and also judicial decisions, legislative proposals, professional positions, and recommendations of international organizations and international jurisprudence.

Analysis of emerging issues requires a new approach, requiring a paradigm shift. By writing this thesis I had an additional aim to make a forum for the elaboration, coordinated and planned research of each subfield, with a well-constructed and defined concept.

In addition, we will try to identify the groups of questions that should be developed and elaborated later by a working group. Our aim is to encourage the setting up of a multidisciplinary working group in which researchers and practitioners could participate alongside the legislator. We would also like to take part in the work of the working group.

\section{THE DRONE AS THE SUBJECT OF LEGAL RELATIONS}

There is a long list about legal relationships in which the drone is displayed as an object of legal relationship, including: sale, gift, transportation, liability for damage caused out of contract, or even a breach of unjust enrichment, finding, and personality rights.

The history of drones dates back to the first half of the $20^{\text {th }}$ century. It was basically developed for military purposes and is currently actively used in this field, and in many cases with models with more than $20 \mathrm{~m}$ wingspan lengths. 
The most important reason for the spread of drones is that, like in case of model flyers, the driver is not on a plane, but controls it from a remote location with a computer or controller, and there is a continuous live-picture connection between the controller and the aircraft. This is particularly important for tactical reasons because it does not directly jeopardize the physical integrity of a pilot in the event of a flight into a dangerous area.

There are multiple attempts around the world to the wide application of drones. For example, Amazon.com wishes to ship their package ordered on their web store (PrimeAir service ${ }^{3}$ ). In the event of various accidents, the defibrillator will be transported on a drone for immediate care. ${ }^{4}$ Agricultural usage will have a potential usage opportunity as well. It will be suitable for police, fire-fighting and disaster protection purposes, as it is possible to fly into dangerous locations without endangering human life or to assess industrial accidents. Larger-capacity devices can even directly contribute to the rescue as they can deliver life jackets, smaller air filters, or oxygen masks for those in danger.

Based on the cumulative sales data of the three most popular drone manufacturers, the graph below shows an increase of more than twice a year, which shows that the number of legal relationships with drones has more than doubled.

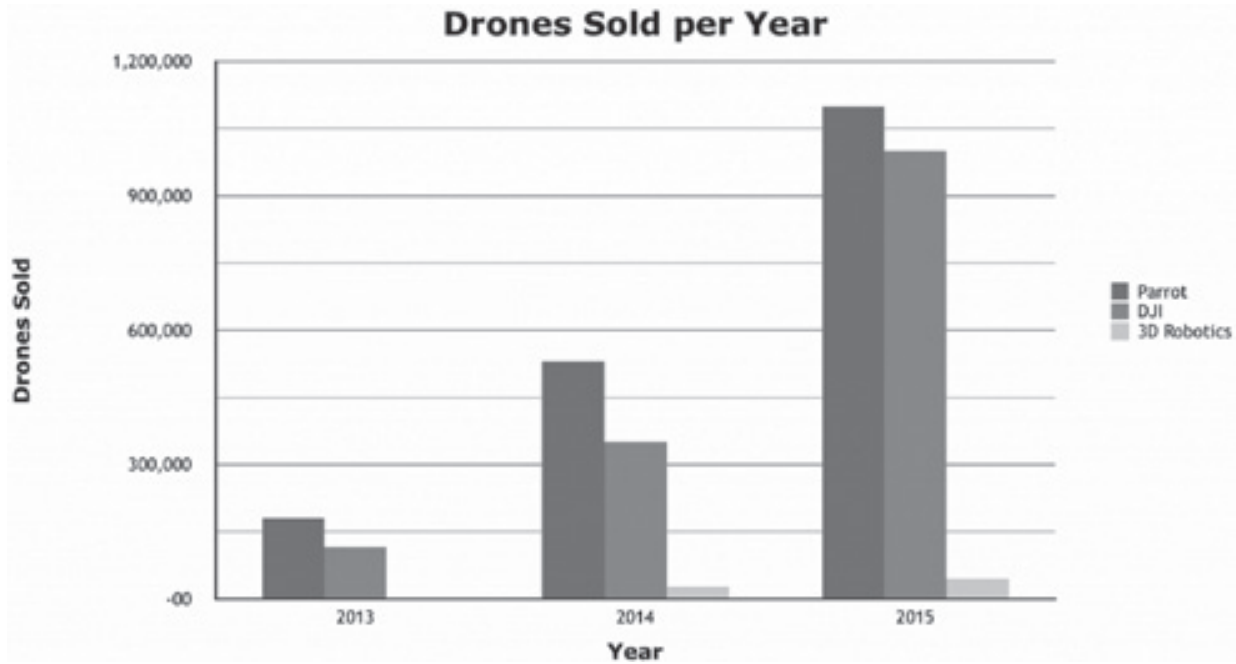

Figure 1 - Estimated drone sales annually. Source: Amato, 2015

\footnotetext{
${ }^{3}$ Amazon Inc, Amazon Prime Air, https:/www.amazon.com/b?node=8037720011 , 17 Apr 2016.

${ }^{4}$ Drone America, Drone America and AMR Collaborate to Make Emergency Drones a Reality.., source: Drone America: http://www.droneamerica.com/news/drone-america-and-amrcollaborate, 04 Dec 2014).
} 
The number of activities carried out by remote control aircraft will increase considerably and this will result in a growing number of new jobs. An American industry study ${ }^{5}$ has predicted that the integration of these devices into the national airspace will create more than 70,000 new jobs in the US over the first three years, with over 13.6 billion USD in economic output. ${ }^{6}$

In Europe, up to 150,000 new jobs are indicated in the same industry by 2050, in addition to maintenance services.

Drone utilization has enormous economic potential both for developing and developed countries, but considering international examples, it is easy to see that the existing aviation regulations are inadequate for their use, as they have technical parameters for which the legislature was/could not be ready for. For their regulation, we are waiting for the creation of detailed and compliant norms in several areas, thinking of life and property protection, personality protection or national security considerations.

Certain technical constraints imposed by some countries' legislators are disproportionate and unrealistic. In the next analysis, I will examine the necessity and usefulness of making the substantive legal norm.

\begin{tabular}{|l|l|}
\hline $\begin{array}{l}\text { Strengths "S" } \\
\text { Appropriate infrastructure to match } \\
\text { technical standards and legislation. } \\
\begin{array}{l}\text { Memberships of international } \\
\text { organizations. } \\
\text { Marketable prices and need for market } \\
\text { demand. }\end{array}\end{array}$ & $\begin{array}{l}\text { Weaknesses "W" } \\
\text { Legislation is far behind technical } \\
\text { innovations. } \\
\text { The lawyer and the legislator do not make } \\
\text { the most adaptable legal statements to } \\
\text { technical progress. }\end{array}$ \\
\hline $\begin{array}{l}\text { Opportunities "O" } \\
\text { As a result of international membership, } \\
\text { the legislator is familiar with precedents } \\
\text { and recommendations. } \\
\text { With proper regulation, the state can earn } \\
\text { significant extra revenue. }\end{array}$ & $\begin{array}{l}\text { Threats "T" } \\
\text { Significant number of users and this } \\
\text { makes controlling much more difficult. } \\
\text { Much of the use of drones is a potentially } \\
\text { dangerous activity }\end{array}$ \\
number of new jobs.
\end{tabular}

Figure 2 - SWOT analysis

${ }^{5}$ Communication from the Commission to the European Parliament and the Council - A new era for aviation - Opening the aviation market to the civil use of remotely piloted aircraft systems in a safe, 2014.

${ }^{6}$ AeroSpace and Defence Industries Association of Europe, ASD estimation 


\section{OUTLINE OF DOMESTIC REGULATIONS FOR DRONES}

Regarding the usage of the drone, that 216/2008/EK European Parliament and Council Regulation about the common rules in the field of civil aviation and establishment of European Aviation Safety Agency, and repealing 91/670/EK Council Regulation, 1592/2002/EK Regulation and 2004/36/EK directive regulation, it declares, that remote controlled aircraft with more than $150 \mathrm{~kg}$ are regulated by the European Aviation Safety Agency. In the case of under $150 \mathrm{~kg}$ cases, it is under the competence of the Member States.

The Act on Aviation in Force ${ }^{7}$ does not explicitly mention drones and no other substantive legal norms are known on this subject, however, the provisions of the Act are considered relevant to the use of drones.

Since these devices are not linked to registration (as we have seen above), their number is unknown in Hungary, but based on an in-depth interview with official representatives, it can be estimated that there over 10,000 in the country and their appearance was observed at the beginning of 2013. Their domestic legislation is in progress, and the staff of the National Transport Authority (NKH) are involved in the preparatory work of the law.

In view of the legal gap, NKH uses analogy until the formation of relevant legislation (and until its entry into force). According to the information provided by the Authority, flights can be divided into two groups - depending on the nature of the task:

Activities carried out with the aim for the purpose of receiving a reward,

Activities carried out privately, for hobby related purposes (without reward)

On this basis, the authority issues "individual licenses" for activities carried out with an aircraft for a reward. For work with a drone, an ad hoc and/or restricted airspace permit is required depending on the activity and work area. It is important to mention that according to $\mathrm{NKH}$, the deadline for normal administration is 21 days, which may be in a positive direction (as it may be necessary to obtain certain other authority resolutions, obtaining security analyses) or in negative directions (if the applicant fulfills all the conditions properly). Depending on the type of airspace required for the operation, both permits are required simultaneously.

The second case is the usage for hobby related purposes (for private use), for which there is currently no need to obtain an authority license. However, it is important to note that in this case, the owner of the vehicle is fully criminally liable for accidents during use and for material damage or for breaches of aviation rules. Based on these, the recommendation according to NKH's statement is as follows: the assets are used only by the owner over the property he owns, i.e. it is

\footnotetext{
${ }^{7} 1995$ XCVII. Act on aviation (hereinafter Lt.)

${ }^{8} \mathrm{NKH}$ terminology
} 
expedient to avoid the property of other natural or legal persons or public areas. It is strongly advisable to avoid flying above people.

One of the biggest questions is that who, where and for what purposes the flight should be allowed? It is conceivable that the devices can be operated by anyone or only with a license or other similar certificate. How old can someone be, and how can the drone be categorized in civil aviation? The current Hungarian legislation, apart from the Lt., affects the use of drones, but does not give clear answers to all questions.

With regard to the future Lt. modification, it is presumed that these standards will have to be adapted to this special aircraft. The elaboration of the detailed rules will in any case require the establishment of a team of experts, since drones may, in certain cases, be subject to specific rules appropriate to their use. ${ }^{9}$

The Hungarian legislation draft is compiled by NKH, taking into account the views of all organizations involved in the use of drones, authorities or security services during the preparation. The draft law will take into account the provisions of Lt., and it is necessary to examine the opinion of the National Media and Communications Authority about spectrum licenses. In addition, consideration should be given to the authorization of aerial remote sensing and the regulation on the use of remote sensing data. In addition, personality issues and possible national security risks arise as well. ${ }^{10}$

It is worth mentioning that, as ratifying international contracts, a historic declaration in the Hungarian legal system, dating back to 1944 and Chicago Conventions, deals with unmanned aerial vehicles as follows: "An aircraft capable of flying unmanned and over the territory of the Contracting States without a pilot, with the special permission of that State and in accordance with the terms of the permit. The Contracting States undertake commitment to inspect unmanned aerial vehicles in the areas open to civil aircraft which ensure the smooth transport of civil aircraft." 11

On September 5, 2016, JEF / 71710/2016-NFM regulation of the Ministry of National Development was published on the amendment of Act XCVII of 1995 on the Public Aviation Act.

The draft contains the following major additions:

It would introduce compulsory electronic contact with non-pilot aircraft during the administration. According to the detailed explanation of the draft law, this would be achieved through the reduction of government bureaucracy, in order to simplify administrative burdens and administrative procedures, this electronic contact would be carried out with unmanned vehicle operators and the request for

\footnotetext{
${ }^{9}$ Government Decree on the use of Hungarian airspace, 4/1998. (I 16)

${ }^{10}$ Boóc, 2015, 219-222.

${ }^{11}$ (25) of Legislative Decree 1971.
} 
licenses, as most of the administrative arrangements (for example: ad hoc airspace applications, registration) between the authority and the client does not necessarily require personal presence.

It would have disposal of those aviation activities with unmanned aerial vehicles which could be continued after notification to the Authority. However, it should be noted that, due to the large number and rapid spread of unmanned aerial vehicles, the scope of the fines would be widened, and in addition to the aviation authority, the police should also be entitled to give a fine.

It would complement the current law that the companies should include the operation of a website and mobile application that supports current airspace information and other restrictions supporting the use of unmanned aerial vehicles. At this point it should be noted that under the Company, we are talking about the HungariaControl Hungarian Air Traffic Services, which is a Private Limited Company. Regulatory control of unmanned aerial vehicles is a prerequisite for the drivers of these vehicles to know which areas or airspace they cannot fly into. Regulatory control of unmanned aerial vehicles is a prerequisite for the drivers of these vehicles to know which areas or airspace they cannot fly into. These areas include a detailed explanation of protected areas and protected objects, areas that are changing in space and time, thinking about disasters, accidents, or the movement of protected persons. In the statutory application, an authorized person may designate unmanned aerial space as a restricted airspace, and through applications, users of the devices may be aware of this, and with this information they may also be aware of the airspace that is prohibited for them.

The draft legislation would define the concept of an unmanned aviation as follows: a civil aircraft designed and operated in such a way that its operation is not carried out by a person on board.

The proposal for modification concerns the training of national and non-national pilots of airplanes and the designations of training personnel, the rules of the airworthiness review, detailed rules for issuing and suspending the airworthiness certificate, and detailed regulations of unmanned aerial vehicle operations and operating regulations, in such a way as it will authorize the minister to draft a decree.

The legislation draft would omit the designation of "non-registered aircraft" and use the term "air vehicle and unmanned aircraft". For a detailed explanation, the two categories will be subject to separate regulation, so the leaving of concept is justifiable. Aircraft models will be subject to the same rules for uniform regulation, as unmanned aircrafts, so the concept of air vehicle model will melt into the concept of unmanned aircrafts. It is to be noted that the detailed rules of the records are not contained in Lt, so they will be transferred to the Ministerial Decrees along with the rules of registration. It is an important development that, for the purpose of regulatory relief, the keeping of the records of the aircrafts - as the 
necessary data is available for them - can be carried out by specially authorized organizations.

The legislation draft has also disposal of air traffic controller license as follows: "There is no need for air traffic controller license for air defence flight attendance." which is replaced by the following text: "There is no need for air traffic controller license for air defence flight attendance, and for unmanned air vehicle if the conditions laid down in the Ministerial Decree on unmanned air vehicles are fulfilled."

\section{CIVIL RIGHTS ISSUES}

\subsection{Civil Rights Liability Issues Related to Drones}

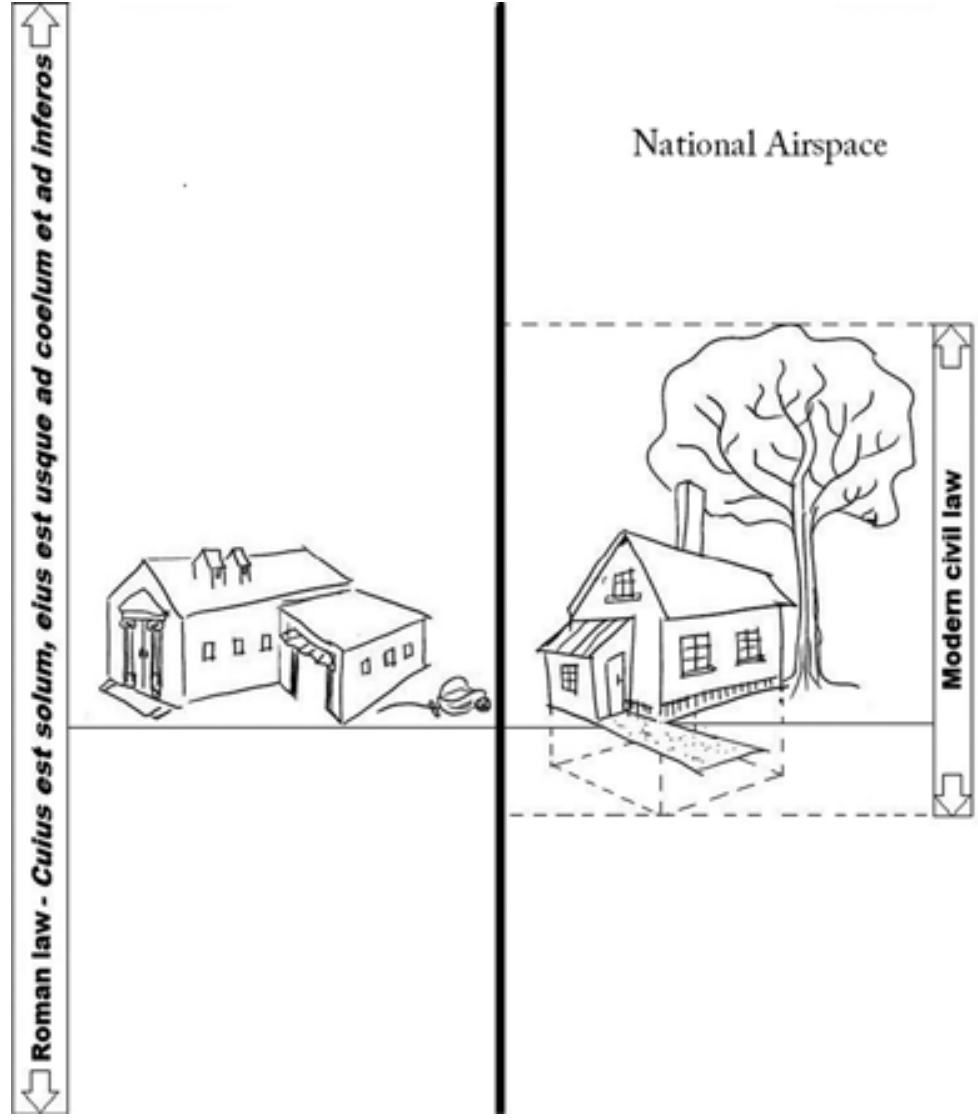

Figure 3 - Illustrating the scope of ownership

Source: The authors own figure 
The above figure serves to illustrate why the current legal approach is problematic for use of the drone just above our own property. John Cobb Copper, an American aviation lawyer, argues that in Roman law thinking the owner of the property (land) has given such rights, that he has unlimited protection in the airspace of his area, without any altitude restrictions. ${ }^{12}$ But in modern civil law, there are big differences in this area, for we know that the state is the sole owner of the airspace and the treasures of the earth's depth under the ground. Based on these, it can be stated that the owner's power only extends until the area where he can build: above until the "chimney top" and down until the "bottom of the cellar". ${ }^{13}$

If we want to establish a delicate responsibility, it is important to think about how to identify the person who is causing the damage or if it is not possible to determine who is responsible for damages? Our first thought may be that the owner is responsible (casum sentit dominus), however, in the case of a remote-controlled device without a current registration and a registered unique identifier (such as a register), the issue is how to reveal the identity of the owner.

The thesis does not intend to detail the distinction between general and dangerous operational responsibilities, but in the knowledge of these, it will be necessary to define the cases in which the drones have general or liability form of responsibility for the increased risk.

What happens if someone harms another? What is the degree to which he is responsible, and based on which code of responsibility should we judge the question? Can there be a meeting of dangerous practices, and if so, what is the basis of judicial practice to decide on the perpetrating ability of the perpetrators?

In the present case, the dangerous practice scope is determined by judicial practice and legal content, and there is currently no established position relating to the drone, therefore it is suggested that not only judicial practice should formulate this question (considering all the circumstances per individual event), but the law determines the cases and parameters in which the use of a drone is considered to be a dangerous practice. This is dictated by simplicity and expediency as well and it is also required, and it also points to uniform judicial practice.

In discussing the responsibility issues, we must first discuss the type of responsibility that the activity with the drone can include. In this case, can we talk about a general responsibility issue if a drone-related activity causes damage? Can conjunctive conditions possibly be necessary for its establishment?

Certification of the unlawful conduct of a damaging person as an objective criterion can be accomplished without further action, since the unlawfulness results from the damage caused, namely, if the law does not make an exception, then all wrongdoing is unlawful, since the law declares the banning of the wrongdoing. ${ }^{14}$

\footnotetext{
${ }^{12}$ Copper, 1968, 55.

${ }^{13}$ Sipos, 2015, 26-28.

${ }^{14}$ BDT2005/1261.
} 
Illicit behaviour must result in damage as an objective criterion.

There must be a causal link between the unlawful behaviour of the perpetrator and the damage suffered as an objective condition. In our view, this condition is realized in most of the cases, since the fact that the perpetrator could not see or anticipate the fact of the damage would be difficult to accept, knowing the dangers of flying.

Lastly, the culpability, that is, the behaviour of the perpetrator in a given situation which is socially expected.

In summary these issues, in our view, the use of a drone is generally an activity with increased risk, but the devices must be differentiated because of their spread and variability.

There are stricter rules than the general damage liability rules when examining the responsibility of the person in charge of a highly risky activity, "Anyone who does an activity with increased risk of damages shall be obliged to compensate for the resulting damage."15

Damage liability arising from a dangerous practice is a special form of damage, as the definition of increased liability does not include wrongful conduct certification. This means that increased liability with an objective nature creates a liability for damages, even if the causative has occurred by accident, however, it is possible to demonstrate the causal link between the damage suffered and the activity with increased risk. ${ }^{16}$

Why is it important to separate the liability forms in examining the question of the liability of drone damages? The answer will be obtained from the judicial practice from which can be seen what law enforcement sees as dangerous practice, and in this round, BDT 2010/2236. should be particularly highlighted, according to which: "A radio-controlled air vehicle model is a dangerous practice, so its operator is responsible for damaging under the rules of liability for activities with a high risk of danger." In this case, the court found that frequency interference was the "internal cause" 17 of the operation and this resulted the uncontrolled state of the aircraft model and thus caused a major accident.

It can be said related to BDT 2010/2236. referenced above, that in a model air vehicle racing contest in 2006 , one of the model aircraft owned by the defendant became unmanageable three minutes after the launch of the demonstration and fell into the audience at high engine speed. As a result of the accident, the claimants' parents lost their lives. The Szekszárd City Public Prosecutor's Office subsequently terminated the investigation against the defendant for reckless endangerment offenses committed within occupation. The reason for the decision

${ }^{15}$ Ptk. 6:535th $\S$.

${ }^{16}$ Sipos, 2015, 25-28.

17 Vékás, Vörös, Tanulmányok az új Polgári Törvénykönyvhöz, 2014, 282.

Vékás, Kommentár a Polgári Törvénykönyvhöz - Kommentár a Polgári Törvénykönyvröl szóló 2013. évi V. törvényhez, 2014, 2269. 
was that the exact cause of the accident could not be established and no result could be expected from the continuation of the investigation.

Claimants brought an action for damages of HUF 46,000,000 against the defendant because, according to their reasoning, the defendant, as the operator of the air vehicle model continues an activity with an increased risk, and he cannot save himself with an unavoidable cause outside the scope of the increased risk activity. The defendant claimed that the action should be dismissed because, in their view, it was not the use of an increased risk of accidents (flying), nor the subject of that (air vehicle model) nor its failure was the cause of the accident, but the outside frequency usage which negatively influenced the air vehicle model management.

In its interlocutory judgment the Court of First Instance stated that the defendant was liable for damages to the claimants as a result of the accident, since the air vehicle model operator was required to be held responsible for the damages caused by the operation of the air vehicle model under the rules of operation. If he wanted to be exempt from liability, he should have demonstrated that the accident was caused by an unavoidable cause outside the scope of the air vehicle model. However, on the basis of the evidence, the precise cause of the accident causing the damage event could not be determined, so it cannot be established that the cause of the damage is unavoidable and is beyond this unavoidable cause for the activity with increased risk.

The case got to second-degree appeal, where the court considered that the evidence obtained by the judicial expert in the course of the investigation and submitted to the trial material provided sufficient evidence to determine the cause of the accident. The court also evaluated the Civil Aviation Security Organization's final report that all types of radio control, whether analogue or digital, and the control equipment are exposed to interference as well. In the field of aerial modelling, frequency interference cannot be excluded.

The court of second instance, unlike the court of first instance, found that the aircraft model accident was caused by the disturbance of the air vehicle's receiving equipment. However, it considered it appropriate to conclude that the operation of the air vehicle model is a highly risky activity and liability should be judged according to the rules of this form of liability.

It is important to point out that the court's reasoning is that frequency interference in the area of radio control is not an unexpected, rarely occurring physical impact, but a physical phenomenon that needs to be expected with all kinds of radio control. The perceived interference disturbance therefore had to be assessed as the cause of the activity with the increased risk. ${ }^{18}$

It can be stated that, if someone does harm by such a device and we judge the question according to "dangerous operation" rules, then the operator of the

\footnotetext{
${ }^{18}$ Published: Judicial decisions: 04/04/2014.
} 
drone can only be exempted from liability for damages caused by the drone if he can prove that the damage is beyond the scope of its activity, and it happened because of an unavoidable reason, so in case of an improper manoeuvre or a technical failure, the operator will be responsible for it.

In the case of a free fall of a device with a total weight of $8 \mathrm{~kg}$, it falls with about $50 \mathrm{~m} / \mathrm{s}$ with $10.000 \mathrm{~J}$ of energy impact rate, while with similar parameters, but with a parachute, this means only $7.2 \mathrm{~m} / \mathrm{s}$ and $205 \mathrm{~J}$ of energy. The speed of about $50 \mathrm{~m} / \mathrm{s}$ means about $180 \mathrm{~km} / \mathrm{h}$ which poses a significant threat, so the form of activity liability with increased risk can be established basically for all drones, except for devices classified as general category of liability by weight, about which I will write in detail in the de lege ferenda proposal chapter.

Even a minor mistake in drone flying can result in serious damage, so clear and quick identification is important in case of damage. Again, I must point out that it will be crucial in the future that the responsible person be properly identified (most likely the owner) and to have adequate coverage for future financial obligations. An appropriate method of identification can be an individual - whether electronic (e.g. chip) or manual (e.g. identification number) - identification for the devices, because if this is not available, then in case of any damage to the device, the operator or owner is unknown.

One of the functions of compensation is the reparation that involves compensating the loss of the injured party as soon as possible (restore balance of wealth). In the above case, the operator/owner will be found only on a disproportionately high cost and time-consuming basis, which could damage this function of compensation.

The current liability insurance system was basically based on aircrafts with pilots. ${ }^{19}$ The weight of air vehicle sets the minimum insurance fee at $500 \mathrm{~kg}$, and the amount of the coverage depending on that. According to my suggestion, this category should be expanded. Appropriate categories should be assigned where there is no need, or there is a recommendation and where there is a mandatory liability for motor liability insurance.

The following two fictitious legal cases are trying to point out what the differences are and similarities between the remote-controlled car and the drone which can be considered as a toy.

\section{Case A}

The adult Tom is playing with his remote-controlled car on the beach (in a section where adults and children play as well), which is recommended by the manufacturer's documentation and is permitted for people over the age of 14 . On

${ }^{19}$ Regulation (EC) No 785/2004 of the European Parliament and of the Council of 21 April 2004 on insurance requirements for air carriers and aircraft operators 
the beach, Mary walks along barefoot towards the hotel, with her recently bought porcelain vase in her hand. Tom detects Mary's approach towards the small car and directs it to another direction, but Mary steps barefoot on the small remote-controlled car directed by Tom, which frightens her (and does not hurt her) and she drops the porcelain vase, which breaks. How will Tom answer for the broken vase?

When solving the legal case, it is unlikely that Tom will be questioned on the basis of the responsibility for the activity with increased risk. According to the rules of general responsibility, Tom can be exempt from the compensation of damages because his conduct to cause damage cannot be determined.

\section{Case B}

Adult Tom is playing with his small size (under $250 \mathrm{~g}$ ) drone on the beach (in a section where adults and children play as well), which is recommended by the manufacturer's documentation and is permitted for people over the age of 14 . Mary walks on the beach towards the hotel with her recently bought porcelain vase in her hand. Tom detects Mary's approach and directs the drone to another direction, but it touches the hand of Mary, which frightens her (and does not hurt her) and she drop the porcelain vase, which breaks. How will Tom answer for the broken vase?

If we do not differentiate, then during the use of drones, it would be a plausible answer that the use of the drone would be a potentially dangerous activity, so Tom could not excuse himself by not being blamed for his activity. Here, we can see that this approach would be exaggerated and disproportionate for a device that is used by underage people (expected to be in an exponentially increasing number) for playing purposes and which can be purchased for a few thousand forints.

\subsection{Data protection aspects of privacy}

From the point of view of privacy, the drone itself would not be a problem, but the technical accessories attached to it would be a problem.

According to the NAIH's recommendation, proper use can also pose serious problems, since "simple" use can mean an intrusion into the private sphere of the person, which collects data in its vision without sorting, the vision of which "is unusually broad in comparison with previous experience of similar technologies and can be changed very quickly." 20

${ }^{20}$ NAIH Recommendation on Data Handling with Drons (National Data Protection and Information Authority Authority, Download date: 16/10/2016, source: http://naih.hu/files/ajanlas_dronok_vegleges_wwwl.pdf, 14 Apr 2014 
Due to the technical capabilities of the drone, it is possible to gather large amounts of data about people in its field of vision, without being conspicuous or noticeable, so hidden observation can easily occur. Practice has been increasingly dealt with by using drones as non-stationary security cameras outdoors.

From the point of view of data protection, the National Data Protection and Freedom of Information Authority (hereinafter referred to as NAIH) lists three categories of civilian drones according to their use:

- public use,

- commercial use,

- private use.

The recommendation does not include military use.

The recommendation also states the extent to which the mere presence of drones can affect the integrity of the private sector and human rights, as follows:

It may cause some changes in the behaviour of the people, preventing them from being obnoxious, with the use of drones the simplest form of violation of the physical and psychological dignity of the individuals can happen, and it is still a problem that the technology for the people is precarious and obtrusive. There may be a high risk of data manipulation other than the original purpose, with applying very advanced technology, which violates human dignity and the anonymity of the human body. The vulnerability of private areas and private homes can also be very high. Exposed negative effects have great significance for the right to freedom and security, freedom of association and freedom of assembly, freedom of religion and expression, and the principle of non-discrimination.

For all three categories, it can be stated that for warranty reasons, certain principles have to be taken into account at the time of application (necessity, proportionality, purpose limitation).

We need to talk about whether camera use is needed and why this may be important, why not optional? Middle price category cameras available nowadays produce have very important management and security features as they transmit real-time image through the drone and in this way they help control the work of the operator and avoid potential dangers. In my view, it can be stated that the conditions of necessity and proportionality are fulfilled in this case and purpose limitation can be objectively determined on the basis of the control of the operator.

In international practice, the decision of the Swedish Supreme Administrative Court published on 21 October 2016 can be highlighted ${ }^{21}$, which prohibits the use of drones with a camera, because based on the reasoning of the decision, drones are

${ }^{21}$ Court of Appeal in Jönköping on December 15, 2015 in Objective 1369-15 (Kammarrätten i Jönköpings dom den 15 december 2015 i mål nr 1369-15), 2016, 78-16

Court of Appeal in Jönköping on December 15, 2015 in Objective 1674-15 (Kammarrätten i Göteborgs dom den 10 juni 2015 i mål nr 1674-15), 2016, 4110-15 
in fact the means of observation and therefore a specific authorization is required. In a detailed explanation, drones were compared to sports cameras fastened to the bicycle steering wheel and on-board cameras equipped to cars and concluded that the latter devices are not a means of observation because they are used by people where they are directly located, but cameras mounted on drones/robotic aircraft are controlled from the ground and cannot be specifically related to the control site, so they are a means of observation. The aforementioned procedures were launched at the initiative of the Swedish Data Protection Authority, which, in their view, may be used for control purposes with the aircraft.

\subsection{Legitimate interest and the protected property}

According to the NAIH, any unreasonable "flight" which may occur within the area of the estate can relate to the field of protection of property. For this purpose, the lawyer/court may request a petition for a property protection proceeding.

In addition, the authority's view is that a "flying" remote-controlled aircraft cannot be subject to the protection of property, since the illegal use does not result in a threat to the power above the subject, but it can only harm the undisturbed use of the (real estate) thing, against which administrative action can be taken.

However, the unauthorized handling of personal data can happen as well, against which authority and court can be appealed for legal remedy. It is important to mention in judging the legitimate security situation that "someone is defending in a legitimate defence position who has previously been unlawfully challenged". An unlawful attack can be an activity that realizes the elements of a criminal offense or a legal offense. The objective aspect of the attack is its unlawfulness.

An attacker must bear the consequences of unlawful attack. In summary, it can be stated that the user of the drone can realize any facts contained in the Criminal $\operatorname{Code}^{22}$ in the light of the particularities of the legal relationship, such as the abuse of personal data, the basic cause of harassment or the form of violation of private defamation against which legitimate protection is available.

\section{DE LEGE FERENDA SUGGESTIONS}

Verification of regulatory need and content of possible regulation

The number of activities carried out with drones is considerably widening and this could lead to the creation of a significant number of new jobs, according to a US industry study, only in the first three years of integration into the airspace,

${ }^{22}$ Act C of 2012 (hereinafter referred to as BTK) 
it will create more than 70000 new jobs. ${ }^{23}$ In Europe, by 2050, 150000 new jobs will be announced in the same industry. ${ }^{24}$

On the basis of these and the potential of the industry, in my view, it can be stated that the legislator cannot rule out the use of equipment, and the limitation of their technical possibilities is also to be considered as an elementary component of these devices, and they can be classified as a component as a function of use.

I would suggest that contact in case of communication with the drone should be available electronically. I suggest making an application for the choice of a suitable location for mobile phones and tablets with which the user can easily get more information thus ensures the implementation of the lawful conduct.

Due to the diversity of uses and the large dispersion of owners' age, it is likely that a large proportion of the owners of drones do not know the aviation regulation properly. Looking at the current market prices, we can assume that in case of flights currently being reimbursed, drone pilots do not have the necessary permits and do not know the current aviation restrictions. This conclusion can be deduced from the fact that the pay dues for self-promoting video makers in these cases do not cover the costs of obtaining the necessary licenses.

The state must ensure that its citizens act in a legitimate manner. They will need to know where and when to take off and where to fly, and where and when their activities are prohibited. This can be helped by a well-prepared smartphone application (an existing example is a UAV forecast, which is not a governmental, but a civil initiative software) from which the operator can find out if the airspace is restricted. The proposed application could take into account the daily airspace utilization plan prepared by HungaroControl and record data. In my opinion, it is much more appropriate to find a solution that does not entail the right choice of airspace for voluntary compliance. Drone manufacturers should be required to integrate "geo-fencing" technology (most of which can be implemented with software updates in the current drone), so this would be a very lucky solution because they could not fly in the forbidden zones despite user management. The Hungarian legislator is also thinking about the application of this technology, and we are pleased to announce that one of the authors has already proposed the use of this technology before ${ }^{25}$ the public plans, and it is a delightful surprise that the legislator also urges this.

Our suggestions may also be useful for future lawyers in addition to lawmakers if they have to rule on a matter that is not regulated, as the guidelines in

${ }^{23}$ Communication from the Commission to the European Parliament and the Council - A new era for aviation - Opening the aviation market to the civil use of remotely piloted aircraft systems in a safe, 2014.

${ }^{24}$ AeroSpace and Defence Industries Association of Europe, ASD estimates.

${ }^{25}$ Szilágyi, G. „Possibilities of Drones Usage in Agriculture”, TDK Conference, College of Szolnok, 26/04/2016 
this paper contrast the technical possibilities and legal anomalies, thereby facilitating the work of well-trained legal practitioners, who are still not familiar with technical innovations.

\section{Civil liability}

Although it can be stated that basically the flying of the drone is an increased risk, in my view it cannot be generalized for every type of drone. It is important that the legislator differentiates between these categories, and later on, judicial practice will be worth considering. In my opinion, a general line of responsibility should be set up between the general responsibility figure and the accumulation of activity with increased risk, for example, whether the asset can be categorized as a gaming category. This category would be too restrictive and would have only a disproportionate amount of remote-controlled aircraft in this category, as most of them specially designed for children are already being offered for use above the age of 14 and the NGM Regulation is intended as toys for children under the age of 14 .

Based on our research, I determined that the basis for differentiation could be based on the weight of the drone and we would recommend limiting it to 250 grams of take-off weight, and above this, the activity with increased risk would be advisable but it would be exaggerated to apply this responsibility. ${ }^{26}$

The current liability insurance system is basically designed for aircrafts with a pilot. The EK Regulation establishes the minimum insurance fee at 500 kilograms and, as a function of this, the collateral amount. Furthermore, the EK Regulation does not apply to aircraft weighing less than $20 \mathrm{~kg}$ maximum takeoff weight (MTOM) but specifically does not have disposal of unmanned aerial vehicles.

It would be advisable for the legislator to extend the regulation and to impose compulsory liability insurance, as it can be stated in connection with the drones that their use mainly covers the concept of increased risk. Furthermore, it would be necessary to identify the assets and the unique identifying mark for owners to identify them clearly (exceptions to the devices to be assessed under the general liability rules in case of damage, as previously indicated by physical parameters). Recording a unique identifier is crucial because we cannot rely on a civil law claim against a device, when its operator or at least is owner cannot be identified. Compulsory liability insurance for the use of a drone would also be crucial because the drone functions as a result of kinematic changes that can cause significant damage and the damage is presumably much higher than the price of the aircraft itself, which justifies that the keeper should have adequate cover provided by such insurance if any person has a claim against civil law. It can be said, however, that

${ }^{26}$ Kurzinformation über die Nutzung von unbemannten Luftfahrtsystemen, 2016 
not all the drones can be classified into the category of dangerous practice and it cannot be expected from any operator of the drone that he has the insurance coverage of the mandatory liability.

My suggestions for EASA drone classifications would have the following categories. The categories would group the expectations against the owner on the basis of the weight of unmanned aerial vehicles, but these categories would be necessary to coincide with the application areas. My recommendation is as follows:

\begin{tabular}{|c|c|c|c|c|}
\hline $\begin{array}{c}\text { Category (by } \\
\text { MTOM weight) }\end{array}$ & $\leq 250 \mathrm{~g}$ & $1 \mathrm{~kg}<$ & $4 \mathrm{~kg}<$ & $25 \mathrm{~kg} \leq$ \\
\hline Classification & Game & \multicolumn{3}{|c|}{ Aircraft suitable for work } \\
\hline $\begin{array}{l}\text { Liability } \\
\text { formation }\end{array}$ & $\begin{array}{l}\text { General } \\
\text { responsibility }\end{array}$ & \multicolumn{3}{|c|}{ Liability for activity with increased risk } \\
\hline $\begin{array}{l}\text { Mandatory } \\
\text { liability } \\
\text { insurance }\end{array}$ & Not necessary & $\begin{array}{l}\text { Not necessary but } \\
\text { recommended }\end{array}$ & \multicolumn{2}{|c|}{$\begin{array}{l}\text { Existence of mandatory } \\
\text { liability insurance regardless } \\
\text { of application area }\end{array}$} \\
\hline Maximum use & $\begin{array}{l}\text { For gaming } \\
\text { purposes }\end{array}$ & $\begin{array}{l}\text { For hobby } \\
\text { purpose }\end{array}$ & \multicolumn{2}{|c|}{$\begin{array}{l}\text { For work and research } \\
\text { purposes }\end{array}$} \\
\hline Age limitation & $\begin{array}{l}\text { Can be used from } \\
14 \text { years of age }\end{array}$ & $\begin{array}{l}\text { From } 16 \text { years of } \\
\text { age }\end{array}$ & \multicolumn{2}{|c|}{$\begin{array}{l}\text { From } 18 \text { years of age (or } \\
\text { from legal age) }\end{array}$} \\
\hline
\end{tabular}

Figure 6 - Author's design for categorizing and judging drones

Source: The author's own figure

In the table, I differentiated them according to the maximum take-off weight and the purpose of use (maximum use possibility), and other features which are also related to this.

\section{Private sector-related privacy issues}

The first major question relating to this issue is whether the use of the camera is necessary when using the drone, and why this may be important, or why should it be omitted? Cameras for mid-price drones available today at affordable prices also have very important management and security features as they transmit real-time images, contributing to the controller's work and avoiding potential dangers. In my view, it can be stated based on these that the conditions of necessity and proportionality are fulfilled in this case and the purpose limitation can be objectively determined, depending on the control of the operator.

It is easy, and seems to be a plain statement that the drone can be identified with cameras equipped to sports aircraft, helicopters, or others. It can be said that they should follow a moving person similar to a drone, but there is a significant difference that the aforementioned devices are easy to detect due to their physical size and tone, 
but the drones can even move unnoticed, their mass and size may be minimal and they can have extremely high speeds and can be well equipped with sensors.

In other comparisons, compared to the popularity of today's popular services, namely Google Steet View ${ }^{27}$, it can be stated that the two technologies are similar in that they take pictures from multiple angles. However, a significant difference is the fact that the service stores static images, but the drones make quicker position changes, making them more dynamic, and the technology is capable of recording real-time online streaming.

Drone technology shows significant technical advances to make it clear that its data management is completely specific, general rules or other special rules currently known are not fully applicable, which justifies the creation of specific rules for it. It is not enough to refer to the rules of a similar regulatory object, or to rely on Infotv. warranty rules, and so because of the data management of the drone special regulation is justified.

\title{
Closing remarks
}

\begin{abstract}
"The desire to fly is an idea handed down to us by our ancestors who... looked enviously on the birds soaring freely through space... on the infinite highway of the air." Orville Wright
\end{abstract}

The aforementioned quotation also symbolizes that all men have thoughts about flying like birds. We could sit on a plane for a long time and we can try out what a bird's eye view is, but we sit there and do not control it. Drone technology gives us the ability to control, although just through a screen, but we can see the world and reach places where we cannot afford to go with our own physical capabilities and we see our world from a different point of view. With our own devices we can see ourselves as a Vasco de Gama of the sky. The law, of course, must be prepared for these "explorers" to designate the boundaries within which they can act and within those limits they can "rule the sky" freely.

In our thesis, I tried to present a wide-ranging and complex picture of anomalies and emerging legal and factual questions that could be the future bases for civil law regulation of unmanned aerial vehicles and in which the lawyer may decide on other aspects.

By writing our thesis, our research is not over, because there are many areas for the use of this future technology, in which we are continually researching and investigating, whether it is a matter of civil law or other legality. We continue to emphasize the usefulness of creating a working group as described in the introduction.

${ }^{27}$ Póczek, A., Drónok és az adatvédelem, Jogifórum, http://www.jogiforum.hu/files/publikaciok/poczek_aliz__a_dronok_es_az_adatvedelem[jogi_forum].pdf, 22 Sept 2015 
Др Вероника Сикора, ванредни иррофесор

Универзитетей у Дебрецину

Правни факулиетеи

szikora.veronika@law.unideb.hu

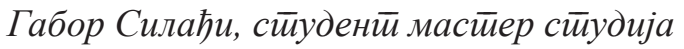

szilagyi.gaben@gmail.com

\section{Нова опасна пракса на видику? Правни аспекти употребе дрона}

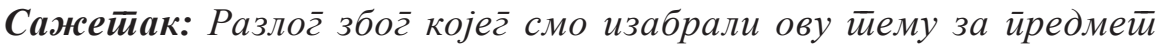
исиираживања су нове иеххнолог̄ије које се йојављују око нас, а йосебно неименована ваздущни уређаји (НВУ). У Мађарској, слично као и у друг̄им земљама, иоостиоји законска ирразнина у йогледу юихове уйойребе.

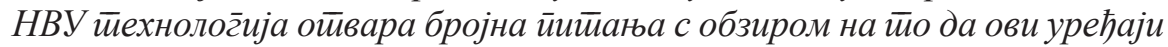

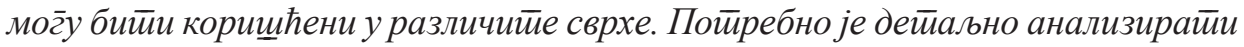
иравни оквир НВУ и ирроменитии нащу иеерсиекиииву, будући да није довољно

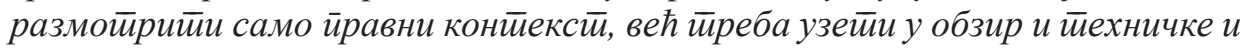
друг̄е асиектие.

Већина академских извора везаних за корищћење НВУ фокусирана је

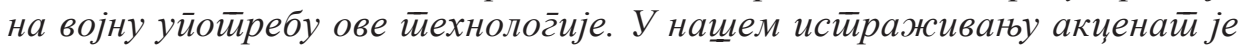

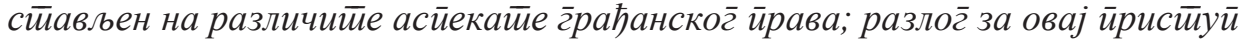
је у тиоме шито размайрамо йравна огрраничења која се иичу уобичајених возила која се користе у свакодневне сврхе, а не за йоиребе државе.

Основни ииљ рада је да истиражи како уйойреба НВУ може иравно да се конйролище. Ово иийање је важно будући да се број ових уређаја

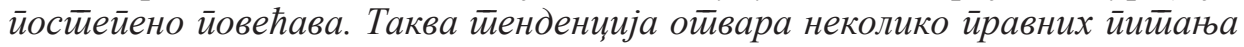
йоиуй иривайностии или накнаде шитетеие.

У овом истиражсиваюу, бавили смо се анализом међународних йравила и регуулатиорних йланова, националних закона и наирйа закона. „Абнормално

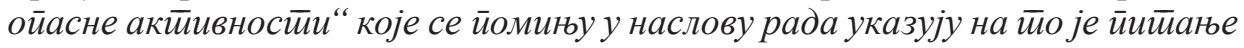
одг̄оворносиии важан асиекеи овог йроблема.

Друг̄и ичиљ нащег̄ рада је да йредложимо формирање радне г̄руйе која би разрадила ова ирравила до детиаља. Они који стиварају иравна иравила и истираживачи би моглли учестивоватии у овој радној груйи заједно са стиручњацима из обалстии тиехнике и иррава.

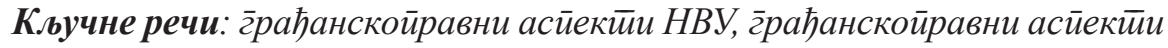

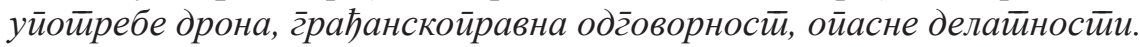

Датум пријема рада: 18.09.2017. 